\title{
ORIENTASI NILAI PENDIDIKAN BISNIS KELUARGA PENGUSAHA PERAK HS SILVER DI KOTAGEDE
}

\author{
Muhammad Iqbal Birsyada, Universitas PGRI Yogyakarta \\ iqbal@upy.ac.id \\ Siswanta, Universitas PGRI Yogyakarta \\ siswanta.upy@gmail.com
}

\begin{abstract}
ABSTRAK
Secara sosio-historis bisnis perak telah lama menjadi identitas industri ekonomi kreatif di Kotagede pada awal abad ke-XIX. Pada tahun 1953 berdiri industri kerajinan perak di Kotagede yang kemudian dinamakan dengan HS. Silver. Perusahaan tersebut mengalami perkembangan pesat dari tahun 1980-an sampai saat ini dengan area pemasaran dalam negeri hingga ke mancanegara. Keberadaan industri ini secara ekonomi mampu membangkitkan perekonomian masyarakat khususnya di sekitar wilayah Kotagede. Berdasarkan latarbelakang tersebut penelitian ini bertujuan menemukan sejarah perkembangan bisnis perak HS. Silver di Kotagede. Kedua, menemukan hubungan kausalitas antara perilaku bisnis pengusaha perak HS Silver di Kotagede dengan nilai-nilai pendidikan keluarga. Ketiga, penelitian ini ingin menemukan proses pewarisan nilai-nilai bisnis dalam keluarga pengusaha perak HS. Silver di Kotagede. Desain penelitian ini menggunakan metode kualitatif dengan pendekatan fenomenologi. Prosedur penelitian ini memfokuskan pada pengkajian terhadap fenomena perilaku pengusaha perak di HS Silver Kotagede. Berdasarkan penjelasanpenjelasan di atas penelitian ini dapat simpulkan sebagai berikut. Pertama, pendiri perusahaan HS. Silver menanamkan nilai-nilai pendidikan bisnis baik kepada keluarga mapun seluruh karyawan melalui wewaler atau nasehat-nasehat yang baik serta memberikan contoh dan pendampingan khususnya ketika di dalam bekerja mengelola bisnis perak. Kedua, terdapat hubungan kausalitas dalam perkembangan kemajuan ekonomi masyarakat di Kotagede khususnya dalam bisnis perak dipengaruhi oleh nilai-nilai etika budaya Jawa (javaneseethics) yang telah lama mengakar dan diwariskan. Ketiga, kemajuan ekonomi masyarakat di Kotagede khususnya pada kelompok pengusaha pengrajin perak dipengaruhi oleh kuatnya jaringan (business network) kerjasama dan pemasaran ke berbagai negara.
\end{abstract}

Kata Kunci: Pendidikan, Bisnis Keluarga, Pengusaha, Perak.

\section{ABSTRACT}

In socio-historical perspective, Silver metallic trade had become an identity of creative industry of Kotagede Yogyakarta in the early 19 century. In 1953 the silver handicraft industry was established which was later named HS. Silver, The company is experiencing rapid development 
from the 1980s to the present with the area of domestic marketing to foreign countries. The existence of this industry is economically able to raise the economy of the community, especially around the Kotagede area. The metallic silver was able to revive the economic development of Kotagede people. Based on this background, this study aims to find the history of HS silver business development. Silver in Kotagede.This study aims to find out the correlation between business ethics and education values taught of HS Silver Family. Besides that, it also tended to find out the learning process of business ethics shown in HS Silver family Kotagede. This study used a qualitative method with phenomenology research design approach. It emphasized the focus studies on the business ethics phenomenon of HS Silver Kotagede.

In conclusion, this study results in a positive correlation between business achievement and Javanese business ethics taught in the family-first, the founder of HS company. Silver instils the values of business education both to families and all employees through a proper authority or advice as well as providing examples and assistance, especially when working in managing silver businesses. Second, there is a causal relationship in the development of the economic progress of society in Kotagede especially in the silver industry influenced by Javanese cultural ethics values (Javanese ethics) which have long been entrenched and inherited. Third, the economic progress of the people in Kotagede, especially in the group of silver craftsmen, is influenced by the strong business network of cooperation and marketing to various countries.

Keywords: Education, Business Ethics, Family Business, Businessman, Silver.

\section{PENDAHULUAN}

Yogyakarta sebagai pusat kebudayaan, pendidikan serta perjuangan pada masa sekarang telah banyak berubah. Yogyakarta yang menjadi tempat tinggal masyarakat Jawa telah mengalami perubahan pesat setelah tahun 2000-an. Secara ekonomi dan budaya, pada saat ini Yogyakarta telah menjadi kota bisnis dengan gaya budaya metropolitan. Bukti dari hal itu adalah adanya sejumlah pusat perbelanjaan seperti Mall atau Plaza menawarkan barang konsumtif dan gaya hidup yang berbeda dari sebelumnya. Secara infrastruktur, kota Yogyakarta sebagai kota kecil yang dikelilingi oleh jalan lingkar atau ringroadsetidaknya dipenuhi oleh 4 Plaza besar dan 6 Mall dan beberapa hypermarket, kini menawarkan gaya hidup baru yang lebih modern, metropolitan dan konsumtif. Suatu gaya hidup yang sebenarnya sangat berbeda dengan gaya hidup ideal orang Jawa seperti urip mung sak madyo, ojo ngoyo, alon-alon waton klakon dan sebagainya (Suharso et al., 2018). Gaya hidup metropolis tersebut dalam prakteknya tidak hanya terjadi pada kelompokkelompok masyarakat perkotaan yang berada di wilayah sekitar pusat pemerintahan akan tetapi juga telah menghinggapi keluarga priyayi kraton.

Secara sosio-kultural apabila dilihat dari segi mobilitas sosialnya, hampir setiap akhir pekan kota Yogyakarta tampak sesak dibanjiri oleh para turis domestik dari berbagai daerah sehingga berakibatmacetnya lalu lintas di 
sepanjang jalan. Kemacetan tersebut salah satunya dapat dilihat pada malam minggu disepanjang jalan menuju kraton dan Malioboro bahkan sampai sepanjang jalan Ngabean. Tidak hanya di dalam kota, di sepanjang jalan ring road kemacetan lalu lintas sudah terbiasa terjadi terlebih pada waktu-waktu jam masuk dan pulang kerja perkantoran. Angkutan masal seperti Trans Jogja di dalam kota-pun seringkali tidak dapat bergerak karena terjebak kemacetan panjang. Belum lagi munculnya trasnportasi online yang jumlahnya kian hari kian tidak terkendali semakin menambah daftar kemacetan kendaraan diberbagai sudut kota. Hal tersebut berbanding terbalik dengan angkutan tradisional seperti andong dan becak yang semakin terpinggirkan. Banyaknya turis mancanegara yang melancong ke Yogyakarta secara tidak langsung juga mempengaruhi pergeseran gaya hidup anak muda Yogyakarta. Pemandangan tersebut dapat dilihat pada malam hari di sepanjang Jalan Prangtritis berjajar cafe kelas elit yang banyak dikunjungi turis mancanegara. Bukti pergeseran nilai dan budayanya lainnya adalah maraknya kenakalan remaja yang sering disebut dengan klitihyang mayoritas pelakunya adalah dari kalangan pelajar (Birsyada and Syahruzah, 2018).

Disamping perkembangan mobilitas sosial serta pergerakan ekonomi di pusat kota Yogyakarta yang amat pesat tersebut, disisi lain di daerah perbatasan kota terdapat industri kreatif masyarakat yang secara kolektif nyatanyata mampu menumbuhkan kekuatan ekonomi penduduk asli setempat. Kotagede adalah salah satu pusat industri kreatif dengan komoditas kerajinan perak secara nyata mampu mengangkat basis nilai-nilai kearifan lokal ke dalam persaingan industri UMKM yang berskala nasional dan internasional. Secara geografis, Kotagede memiliki luas wilayah 3,07 $\mathrm{Km}$ yang berada pada ketinggian $113 \mathrm{~m}$ dpl dengan suhu maksimum 32 derajat Celsius. Jarak Kotagede dengan pusat pemerintahan Yogyakarta adalah 0,75 Km. Pada sebelah timur, Kotagede berbatasan dengan Kecamatan Banguntapan. Pada sebelah barat berbatasan dengan Kecamatan Umbulharjo. Sebelah utara berbatasan dengan Kecamatan Banguntapan. Pada sebelah selatan juga berbatasan dengan Kecamatan Banguntapan (sumber Badan Pusat Stastika Yogyakarta, 2018). Secara historis, Kotagede merupakan pusat pemerintahan kerajaan Mataram Islam yang didirikan oleh Panembahan Senopati sejak Abad ke-XVI dan XVII yang dahulunya berupa hutan Mentaok.

Secara historis, pada era pemerintahan Sultan HB VIII Kotagede mengalami perkembangan pesat terutama dalam hal bisnis kerajinan perak sehingga disebut zaman perak. Beberapa factor yang mempengaruhi adalah modal, kecakapan wirausaha, inovasi teknis, dan sebuah pasar baru (Nakamura, 2017:117). Pada saat usaha kerajinan perak tersebut menunjukkan kesuksesannya, pihak kraton melalui Pakaryan Ngayogyakarta memberinya subsidi berupa 1500 gulden setiap tahunnya. Selain itu menyediakan ruang pameran sekaligus menghubungkannya dengan jaringan perdagangan internasional. Pada tahun 1935-1938 terdapat 78 perusahaan perak yang dalam satu tahun dapat memproduksi perak sebanyak 25.000 kilogram perak (Nakamura, 1983). Melalui kegiatan usaha kerajinan tersebut, sejak zaman pra kemerdekaan, Kotagede mengalami kemajuan ekonomi secara pesat serta mampu menggerakkan ekonomi kreatif sehingga mampu meningkatkan taraf hidup masyarakat. 
Apabila dilihat secara sosio-historis, kemajuan masyarakat Kotagede Yogyakarta dalam dalam hal usaha kerajinan perak dan batik sehingga mampu memberdayakan taraf hidup masyarakat kaum lemah adalah karena nilai-nilai kebudayaan yang bersumber dari ajaran Islam yang dipelopori oleh organisasi Muhammadiyah. Banyak dari keluarga kaum pengusaha perak dan batik yang sukses dalam membangun bisnisnya hingga memiliki jaringan sampai ke luar negeri selain karena kekuatan paguyuban pengrajin perak adalah karena afiliasi mereka dengan organisasi Islam puritan seperti Muhammadiyah. Spirit gerakan Muhammadiyah mampu mengembangkan masyarakat Kotagede menjadi maju secara sosio-ekonomi (Nakamura, 1983; Birsyada, Wasino, S. Suyahmo, et al., 2017). Singkatnya, perkembangan bisnis perak dan nilai-nilai budaya keagamaan seperti sebuah mata uang logam satu dengan lainnya saling beriringan.

Pada saat ini jaringan pengusaha Perak di Kotagede semakin menunjukkan peningkatannya dengan produksi yang bervariasi bentuk dan macam corak seninya. Berdasarkan data-data lapangan, didapatkan bahwasanya rata-rata para pelaku bisnis perak diwariskan secara turun temurun dari generasi ke generasi dengan desain menyesuaikan pasar. Pusat pengrajin dan pengusaha perak pada saat ini dapat dijumpai salah satunya adalah berada di kampung Sayangan kelurahan Jagalan yang berada di sebelah utara Masjid Kotagede. Ada dua paguyuban besar yang menaungi para pebisnis perak diantaranya adalah Kelompok Pengrajin Perak Yogyakarta (KP3Y) dan Selaka Kotagede. Banyak turis baik domestik maupun mancanegara yang langsung datang ke lokasi pengrajin kemudian memesan cenderamata yang terbuat dari perak sesuai selera keinginan mereka.

Biasanya para turis asing lebih suka bentuk-bentuk kerajinan perak yang warnanya agak pudar atau kusam seperti tampak klasik atau antik. Dengan demikian mereka meminta pengrajin perak untuk membuatkan aneka kerajinan perak sesuai pesanan mereka tersebut dengan harga sesuai dengan tingkat kerumitan motif dan lamanya proses pembuatan kerajinan perak yang di pesan tersebut. Beberapa pengusaha perak juga bekerjasama dengan pihak maskapai penerbangan seperti Air Asia Foundation. Hasil produksi dari kerajinan perak yang diekspor ke luar negeri adalah yang dianggap paling berkualitas selain itu juga menyesuaikan selera pesanan pasaran internasional.

Beberapa toko perak dalam skala besar yang dapat ditemui di Kotagede diantaranya adalah: toko HS Silver, Narti Silver, Tom Silver yang berada di sebelah barat jembatan. Sedangkan pengusaha perak dalam skala kecil mereka melakukan produksi dan promosi pemasaran dengan cara menunggu pesanan dari para pembeli secara langsung. Pengusaha-pengusaha perak skala kecil juga dapat dilihat di toko-toko perak sepanjang jalan menuju pasar Kotagede. Perusahaan perak dalam skala kecil kebanyakan bergabung dalam paguyuban Selaka Kotagede. Sedangkan perusahaan perak dalam skala besar bergabung dalam KP3Y. Selain karena kekuatan jaringan paguyuban perak yang kuat, peran serta dari Pemerintah Kota Yogyakarta dalam melakukan pendampingan UMKM pengrajin perak dilakukan secara serius sehingga baik kuantitas maupun kualitas dari hasil olahan kerajinan perak tiap tahun semakin meningkat. Adapun bentuk-bentuk kerajinan peraknya diantaranya adalah motif cincin dan daun. 
Majunya kekuatan ekonomi masyarakat di Kotagede yang salah satunya ditopang oleh kelompok pengrajin perak secara otomatis berimplikasi berimplikasi pada pemasukan Pendapatan Asli Daerah (PAD) pemerintah DIY. Selain itu, industri ekonomi keratif tersebut dapat menambah daya tarik destinasi pariwisata yang memiliki ciri khas tersendiri. Menurut laporan hasil penelitian Statistika Ekonomi Kreatif (Bekraf) serta Badan Pusat Statistika (BPS) menjelaskan bahwa terdapat Rp. 852,24 triliun pada besaran PDB ekonomi kreatif pada kisaran tahun 2010 sampai 2015. Hal tersebut berarti terdapat peningkatan secara signifikan pendapatan PAD dari sebelumnya yang hanya Rp.525,96 triliun.Hal tersebut sekaligus menunjukkan bahwasanya ekonomi kreatif merupaka pilar dari kekuatan perekonomian nasional.

Selain kekuatan ekonominya, dalam hal agama dan tradisi masyarakat Kotagede juga memiliki ikatan batin yang kuat. Secara religi, mayoritas penduduk adalah beragama Islam. Secara kultural ikatan tadisi budaya yang dipraktekkan diantaranya adalah melalui beberapa tradisi seperti nawusendang, jenang suran dan pasar legi. Adapula tradisi kirab budaya ambengan agung berupa mengarak gunungan kuliner oleh ratusan abdi dalem kraton Ngayogyokarto.

Berdasarkan latar belakang di atas penelitian ini ingin mengkaji sekaligus menemukan dua aspek. Pertama, penelitian ini ingin menemukan hubungan kausalitas antara perilaku bisnis pengrajin perak di Kotagede dengan nilai-nilai budaya. Kedua, penelitian ini ingin menemukan proses pewarisan nilai-nilai pendidikan bisnis dalam keluarga pengusaha perak khususnya pada pengusaha HS Silver di Kotagede. Dengan hal tersebut hasil dari penelitian ini dapat dijadikan sebagai basis pengembangan penelitian sosial, ekonomi sekaligus kebudayaan khususnya yang memiliki fokus pada pewarisan nilai bisnis masyarakat.

Berbagai penelitian tentang perilaku ekonomi masyarakat telah banyak dikaji oleh para ilmuan dan akademisi. Sebagian dari mereka menitik beratkan pada pengaruh perilaku ekonomi yang dikaitkan dengan sumber dari kebudayaan. Studi Clifford Geertz tentang perilaku ekonomi kaum muslim reformis-puritan menghasilkan beberapa temuan teoritik. Dalam salah satu riset di Kediri, Jawa Timur pada awal 1960-an, Geertz menemukan banyak pengusaha di kota kecil tersebut yang berafiliasi pada organisasi yang berbasis nilai Islam modernis (Geertz, 1977). Kaum muslim modernis inilah yang kemudian mengkontekstualkan spirit kebudayaan yang bersumber dari ajaran Islam dengan kemajuan perekonomian di Mojokuto. Hal tersebut ditandai dengan perilaku sehari-hari mereka sangat bekerja keras dan hemat sehingga dapat mengembangkan perekonomian kota di Kediri. Namun dalam temuannya, Geertz mengemukakan bahwa kesuksesan muslim modernis dalam mengembangkan basis ekonomi di Mojokuto tidaklah semata-mata karena spirit budaya puritanism sebagaimana spirit ajaran protestan. Geertz menemukan, kesuksesan ekonomi mereka yang paling terbesar adalah karena faktor kekuatan organisasinya.

Sedangkan dalam kajian (Castles, 1982) yang mengamati secara mendalam perilaku munculnya kaum wirausahawan di Kudus dikarenakan oleh pergerakan ekonomi yang dilakukan oleh para santri yang reformis. Dalam studinya ditemukan secara umum bahwasanya pengusaha santri yang bergerak 
dibidang industri rokok adalah para santri yang memiliki spirit reformis yang tinggal di wilayah Kauman. Menurutnya pengaruh munculnya golongan kapitalis dari kalangan santri ini adalah mereka yang memiliki pandangan kebudayaan yang bersumber dari ajaran agama puritan. Akan tetapi semangat puritanisme tersebut secara realitas bukanlah hal yang sangat menentukan dalam pengembangan usaha mereka. Namun hal yang paling menentukan adalah posisinya yang terasing dari lingkunganya (alienasi). Mereka secara simbolik berusaha mempertahankan panji-panji keislamannya dan berusaha untuk menjadi orang kaya agar dapat mempengaruhi lingkungan sekitarnya dalam mentaati agama Islam.

Hasil studi lain tentang kemajuan ekonomi masyarakat juga dilakukan oleh (Nakamura, 1983) menemukan bahwasanya kemajuan ekonomi masyarakat Kotagede Yogyakarta dalam bidang ekonomi dan pemberdayaan masyarakat kaum lemah karena spirit kebudayaan yang bersumber dari ajaran Islam yang dipelopori oleh organisasi Muhammadiyah. Spirit gerakan Muhammadiyah mampu mengembangkan masyarakat Kotagede menjadi maju secara sosio-ekonomi. Selain karena terpengaruh etika organisasi puritan juga karena peranan penguasa elit lokal dalam hal ini Sri Sultan Ngayogyokarto yang berusaha keras memajukan perekonomian di seluruh wilayah Yogyakarta.

Kajian senada dengan (Nakamura, 1983) juga dilakukan dalam Studi (Nasir, 1999) menemukan bahwasanya para pengusaha muslim yang sukses dalam mengembangkan ekonominya di Indonesia kebanyakan adalah terpengaruh oleh spirit aliran jamaah tasawuf yang tergabung dalam Thariqah Qadariyyah, sedangkan dari pengikut Tharaiqah Asy'ariyyah lebih banyak dianut oleh para buruh. Berbeda dari studi (Nasir, 1999), penelitian (Mulkhan, 2002) pada pengusaha muslim di Kudus Kulon Jawa Tengah sebagian besar adalah penganut aliran tasawuf yang tergabung dalam Thariqah Shadzaliyyah. Singkatnya, menurut Mulkhan, faktor ideologi tidak serta merta bisa menjelaskan kesuksesan bisnis seseorang. Demikian pula dengan hasil studi (Qodir, 2002) yang meneliti aktifitas bisnis masyarakat Pekajangan Pekalongan yang ternyata sebagian besar mereka berafiliasi dengan organisasi Muhammadiyyah.

Studi lain tentang kemajuan ekonomi masyarakat dilakukan oleh Sobary (Sobary Muhammad, 2007) berusaha menghubungkan antara tesis Weber dengan dinamika perekonomian masyarakat muslim di Indonesia. Dalam bukunya Etika Islam: Dari Kesalehan Individual Menuju Kesalehan Sosial Sobary menemukan adanya korelasi yang cukup signifikan antara etos kerja dan spririt gerakan wirausaha yang bangkit dari kesadaran ajaran keberagamaan. Studi ini mengambil lokus di masyarakat Suralaya, sebuah perkampungan Betawi di perbatasan antara Jakarta dan Jawa Barat. Sobary telah membuktikan bahwa tesis Weber tidak sepenuhnya bisa diterima. Spirit puritanisme yang ditunjukkan oleh masyarakat Suralaya tidak sekuat masyarakat calvinisme sebagaimana yang dikaji oleh Weber. Sobary mengemukakan bahwa penduduk Suralaya bernasib beda dengan di Barat, meskipun sama memiliki pemahaman mengenai peran agama sebagai etika perkembangan ekonomi. Jika di Barat, ajaran Protestan mampu mengangkat mentalitas kapitalisme dalam banyak kalangan dan berkembang menjadi kapitalisme modern. 
Selain studi (Sobary Muhammad, 2007)kajian Ridwan Muhtadi (Ridwan Muhtadi, 2011) tentang Pola Pemahaman Agama dan Perilaku Ekonomi Masyarakat Perajin Tempe Di Kelurahan Purwantoro Kecamatan Blimbing Malang. Asumsi utama yang diajukan dalam penelitiannya adalah pemahaman tentang spiritkeagamaan masyarakat memiliki pengaruh yang kuat dalam membentuk perilaku sosial ekonomi. Hasil penelitiannya menunjukkan bahwa pemahaman ajaran agama semata tidak selalu berhasil mengejawantahkan apa yang dipahami dengan apa yang harus dipraktikkan. Tindakan sosial dan ekonomi masyarakat rupanya dipengaruhi oleh faktor-faktor lain di luar nilainilai ajaran agama. Singkatnya, mereka yang berhasil justru mereka yang bekerja keras di siang hari (profitoriented) dan tetap bergumul dalam berbagai kegiatan sosial (social oriented) dan kegiatan keagamaan (transenden) di malam hari. Kombinasi antara kedua sikap dan perilaku yang sering disebut 'berbeda' ini justru melahirkan sikap sosial yang memiliki kontribusi positif untuk perkembangan ekonomi masyarakat.

Kajian senada dengan (Ridwan Muhtadi, 2011) juga dilakukan oleh (Pujiono, 2010) yang meneliti perilaku ekonomi warga Nahdhatul Ulama (NU) di Pasuruan Jawa Timur. Hasil temuan menunjukkan bahwasanya perilaku ekonomi warga NU di Kabupaten Pasuruan Jawa Timur tidak selalu terikat oleh hasil keputusan hukum Bahshul Masail Pimpinan Pusat NU. Studi Kersten (2013) bertujuan memahami konsep pandangan spirit ajaran moral Islam dengan kehidupan sosial masyarakat Jawa. Menurutnya, Re-aktualisasi nilai-nilai karakter keagamaan dalam Islam sangat berpengaruh dalam pengembangan perubahan sosial dan kebudayaan pada masyarakat Jawa dan Indonesia. Hasil kajiannya menitik beratkan dari karya Mark Woodward sebagai berikut. Pertama, secara teoritis memperlihatkan ada hubungan yang sangat kuat antara spirit budaya yang bersumber dari ajaran Islam pada perilaku masyarakat Jawa. Spirit budaya dan ajaran agama tersebut telah berakulturasi menjadi sebuah corak pandangan Islam yang lebih ke-arah sinkretik. Dan pada masa Orde Baru hingga reformasi spirit kebudayaan yang bersumber dari nilai-nilai ajaran Islam yang bercorak modern-lah yang menjadi penggerak utama kebangkitan kemajuan Islam di Indonesia sedangkan kebudayaan Islam yang becorak sinkretik hanya bergerak dalam wilayah lokal Jawa khususnya kraton.

Jika dalam kajian Kersten (2013) menemukan praktek islam di Jawa lebih bersifat sinkretik maka penelitian Jalil (2012) dengan judul Spiritual Entrepreneruship pada pengusaha muslim di Kudus Jawa Tengah. Hasil temuannya adalah pengusaha muslim Kudus yang sukses dalam membangun basis ekonomi keluarga dan masyarakat sebagian besar adalah yang berafiliasi dengan organisasi NU. Jika Jalil (2012) mengkaji etika bisnis kaum santri di Kudus maka (Wasino, 2014) mengkaji etika bisnis kaum priyayi Jawa di praja Mangkunegaran pada masa pemerintahan Mangkunegara VI dan VII. Hasil penelitian menemukan bahwasanya nilai-nilai budaya Jawa Mangkunegaran yang dijunjung tinggi oleh segenap masyarakat dan elit praja Mangkunegaran berpengaruh signifikan dalam mempengaruhi kemajuan ekonomi di praja Mangkunegaran.

Senada dengan hasil temuan Wasino (2014), Muhammad Iqbal Birsyada and Et.al, (2016) juga menemukan bahwasanya kemajuan ekonomi dan bisnis 
di praja Mangkunegaran salah satu faktor utamanya adalah terenkulturasinya nilai dan etika Jawa Mangkunegaran. Begitu pula dengan studi Birsyada, Wasino, Suyahmo, et al., (2017) yang mengkaji perilaku bisnis yang dilakukan oleh KGPAA. Mangkunegara IV menghasilkan temuan bahwa etika bisnis Mangkunegaran berpengaruh signifikan sebagai penggerak ekonomi praja Mangkunegaran yang salah satunya didasari atas etika dan nilai-nilai ajaran tasawuf yang bercorak Sufi. Jika pada masa pemerintahan KGPAA. Mangkunegara IV wilayah Mangkunegaran mengalami kemajuan dan kemakmuran ekonomi maka dalam kajian (Suharso et al., 2018) tentang gaya hidup ekonomi kelas menengah pada kelompok priyayi di Yogyakarta justru yang terjadi sebaliknya (Suharso et al., 2018). Kaum priyayi Yogyakarta telah mengalami banyak pergeseran. Di antara pergeseran-pergeseran tersebut adalah pergeseran nilai-nilai etika Jawa. Kaum priyayi di Yogyakarta secara praksis kurang mampu mengembangkan nilai-nilai etika budaya Jawa khususnya dalam hal bisnis. Singkatnya, secara kultural, perkembangan kemajuan ekonomi pada keluarga priyayi kelas menengah tidak diimbangi dengan penguatan basis nilai dan kultural yang kuat.

Kajian terakhir tentang kehidupan Yogyakarta dari sisi sosio-kultural dilakukan oleh Birsyada dan Syahruzah (2018) tentang pergesaran nilai di Yogyakarta dulu hingga kini di mana Yogyakarta pada masa kini banyak berubah karena beberapa faktor di antaranya faktor eksternal dan internal (Birsyada and Syahruzah, 2018). Faktor internal adalah kontrol sosial masyarakat yang mulai melemah. Kedua adalah faktor mobilitas sosial masyarakat yang semakin meningkat. Perbedaan penelitian ini dengan penelitian sebelumnya adalah jika pada penelitian-penelitian sebelumnya banyak membahas hubungan kausalitas antara kemajuan ekonomi dengan nilainilai keagamaan maka pada penelitian ini lebih menitik beratkan pada proses pewarisan nilai pendidikan dan budaya bisnis pada pelaku ekonomi khususnya pada pengrajin pengusaha perak HS. Silver di Kotagede. Penelitian ini secara spesifik ingin mengetahui sekaligus menemukan nilai-nilai pendidikan bisnis yang di wariskan dari usaha bisnis perak HS. Silver.

\section{METODE PENELITIAN}

Penelitian ini merupakan penelitian kualitatif dengan pendekatan fenomenologi. Penelitian ini merupakan studi narasi yang berfokus pada cerita atau deskripsi tentang serangkaian peristiwa terkait dengan fenomena sosial berdasarkan pengalaman hidup seseorang atau kelompok masyarakat secara utuh yang disajikan secara naratif (Creswell, 2015). Prosedur penelitian ini dimulai dengan memfokuskan pada pengkajian terhadap fenomena perilaku pebisnis perak di HS Silver Kotagede. Pengumpulan data melalui wawancara mendalam mereka seperti pelaporan pengalaman individual pelaku bisnis perak HS Silver, kelompok sosial dan penulisan secara kronologis atas makna dari pengalaman tersebut atau menggunakan tahapan perjalan hidup (life course stages). Selain itu, penelitian ini dalam pengumpulan data menggunakan kajian literatur dan pengumpulan dokumen-dokumen khususnya yang berhubungan dengan perkembangan bisnis perak di Kotagede serta seputar sejarah dan kebudayaan masyarakat Kotagede. Hasil dari kajian penelitian akan dianalisis 
menggunakan teori sosial dan kebudayaan. Perjalanan hidup masyarakat yang akan dikaji dalam penelitian ini adalah fenomena kesuksesan pelaku bisnis pengusaha pengrajin perak di Kotagede khususnya di HS Silver.

Berdasarkan penjelasan di atas, untuk mengumpulkan cerita dari individu satu hingga individu lain, peneliti mempergunakan teknik pendekatan restorying yaitu proses reorganisasi cerita menjadi beberapa jenis kerangka umum. Kerangka umum cerita tersebut dapat disusun melalui pengumpulan cerita, menganalisisnya untuk menemukan unsur-unsur penting dari cerita informan kemudian ditulis kembali cerita tersebut dalam sebuah rangkaian kronologis (Creswell, 2015). Cerita perjalanan hidup pelaku bisnis kerajinan perak HS Silver di Kotagede yang menjadi fokus dalam penelitian ini akan dibandingkan pula dengan hasil wawancara pelaku bisnis sejenis yang lainnya serta beberapa sumber yang relevan.

Selain melakukan wawancara mendalam dengan keluarga HS Silver, sumber data penelitian ini adalah literatur yang relevan sesuai dengan tema. Literatur yang digunakan adalah mengenai tema hubungan kausalitas antara perilaku bisnis kelompok masyarakat yang didapat dari buku dan jurnal ilmiah yang relevan sesuai tema penelitian. Sumber wawancara mendalam selain pada pengusaha bisnis perak juga dilakukan wawancara kepada para pekerja termasuk buruh dan keluarganya. Pada penelitian ini, peneliti menjadi dan membuat instrumen penelitian sendiri.Penelitian ini mempergunakan analisis deskriptif verifikatif. Tehnik analisis data dalam penelitian ini yang digunakan adalah: (1) Reduksi data, (2) display data, (3) mengambil kesimpulan dan verifikasi (Rachman, 2015).

Berdasarkan penjelasan dari beberapa tahap di atas lebih jelasnya dapat dijabarkan sebagai berikut: Pertama, reduksi data dalam hal ini adalah proses pengelompokkan data yang dipilih untuk menjawab permasalahan yang sedang diteliti. Pada penelitian ini penulis mengumpulkan informasi sebanyakbanyaknya dari informan penelitian, dengan menggunakan teknik pengumpulan data, selanjutnya penulis mengelompokkan informasi yang diperoleh sesuai dengan kebutuhan. Informasi yang akan diperoleh adalah dengan melalui wawancara mendalam seputar perilaku pengusaha kerajinan perak HS Silver di Kotagede. Adapun yang menjadi pokok tema wawancara yang akan dilakukan proses katagorisasi diantaranya adalah: sejarah hidup keluarga, sejarah perkembangan bisnis kerajinan perak, produk kerajinan perak, manajemen pemasaran, jaringan bisnis perak HS Silver.

Langkah kedua, display data dalam hal ini adalah penyajian data dan informasi yang telah terkumpul dalam bentuk matrik atau uraian yang memberikan kemudahan dalam memberikan kemungkinan penarikan kesimpulan dan pengambilan tindakan yang diperlukan. Pada tahap ini peneliti mengelompokkan temuan-temuan lapangan menggunakan tabel, matrik sesuai katagorisasi instrumen yang telah peneliti susun sehingga dapat dilihat secara jelas hasil temuan di lapangan. Langkah ketiga, penarikan kesimpulan (verifikasi), proses pencarian arti/makna dari data yang terkumpul, memberikan catatan keteraturan, pola-pola yang dapat digunakan untuk menjelaskan, konfigurasi yang mungkin digunakan, alur sebab akibat serta proposisi. Dalam penarikan kesimpulan peneliti menggunakan teknik triangulasi yang meliputi triangulasi sumber, penelitian sejenis dan teori. Hasil 
temuan dianalisis kembali dengan merujuk pada teori nilai dan kebudayaan serta penelitian sebelumnya. Pada tahap ini peneliti kemudian menganalisis hasil-hasil temuan lapangan yang sebelumnya telah disajikan dalam tabel, matriks temuan untuk selanjutnya dilakukan proses triangulasi data.

\section{HASIL PENELITIAN DAN PEMBAHASAN}

Secara geografis, wilayah Kecamatan Kotagede terletak didaerah pinggiran kotadengan batas-batas: Sebelah Utara: Kecamatan Banguntapan, Kab Bantul. Sebelah timur: Kecamatan Banguntapan, KabBantul. Sebelah Selatan berbatasan dengan Kecamatan Banguntapan, Kabupaten Bantul. Sebelah Barat berbatasan dengan Kecamatan Umbulharjo. Di sisi lain kondisi Geografis secara garis besar Kecamatan Kotagede adalah wilayah dataran rendah, yang dilintasi oleh sungai Gajah Wong. Ketinggian tanah dari permukaan laut : 113,00 m, sedangkan jarak dari kantor Kecamatan ke Kelurahan Prenggan adalah 0,5 km - Kelurahan Purbayan: 1,00 km, sedangkan Kelurahan Rejowinangun: 1,00 km (BPS. Kotagede Dalam Angka 2018). Perusahaan HS Silver 800-925 merupakan salah satu perusahaan perak terbesar di Yogyakarta yang terletak di Jalan Mondorakan No.1, Prenggan, Kotagede Yogyakarta. Secara historis, perusahaan ini beroperasi sejak tahun 1953 didirikan oleh Bapak dan Ibu H. Harto Suharjo (HS) di mana semula bergerak hanya dalam bidang perhiasan imitasi dengan nama "Terang Bulan".

Pada tradisi perkembangan ekonomi masyarakat Jawa aktor penting tidak selalu didominasi oleh kaum laki-laki. Dalam struktur birokrasi Jawa klasik hubungan sosial antara keluarga kerajaan dan rakyat satu diantara lainnya saling terkait yakni hubungan mikrokosmos dengan makrokosmos antara jagad cilik dengan jagad gede mengupayakan kehidupan yang selaras dan harmonis. Oleh sebab itu sebuah pemerintahan atau sebuah tatanan kehidupan dalam suatu masyarakat akan dianggap baik ketika satu dengan yang lainnya mampu memenuhi kewajiban-kewajibannya menciptakan ketentraman batin bagi anggotanya tidak terkecuali dalam lingkup sebuah keluarga (Moertono, 2017). Dalam mengarungi kehidupan keluarga, orang Jawa diharuskan sabar menerima segala apa yang terjadi pada dirinya dan senantiasa berdoa mengharap keslamatan pada diri dan keluarganya. Oleh sebab itu ciri khas ritus yang melekat pada masyarakat Jawa adalah upacara slametan (Magnis-Suseno, 1988). Tradisi tersebut berkembang mulai dari pusat kerajaan (kraton) yang mengalami proses percampuran antara Hindu, Budha dan islam atau sering disebut sinkretik (Koentjaraningrat, 1994).

Dalam hal perjuangan hidup, peranan kaum perempuan Jawa ternyata banyak menentukan langkah perjalanan hidup keluarga secara signifikan. Dalam beberapa studi literature tentang sepak terjang kehebatan perempuan Jawa menunjukkan bahwa perempuan Jawa secara universal dianggap lebih unggul dalam hal mengelola keuangan dan bisnis disbanding kaum pria bahkan suami mempercayakan urusan keuangan sepenuhnya kepada istrinya. Bahkan dalam hal jual beli di pasar kaum perempuan memegang kendali penuh. Singkatnya kemampuan perempuan dalam mengelola keuangan keluarga memegang peranan kunci dalam menentukan derajat perempuan itu sendiri (Carey dan Houben, 2016). 
Pandangan-pandangan di atas sejalan denganapa yang dialami di perusahaan perak HS. Silver Kotagede Yogyakarta yang pada saat ini berkembang pesat salah satunya akrena peranan sentral dari seorang istri yang tangguh lagu ulet dan tekun. Pada awalnya sekitar tahun 1950-an, Ibu Harto hanya menitipkan hasil kerajinan perak imitasi yang dibuatnya sendiri di tokotoko pasar Beringharjo. Dengan demikian sebenarnya menjadikan Ibu Suharto harus mengeluarkan anggaran untuk biaya produksi dua kali lipat sebab barang dagangan yang dititipkan tidak lantas terjual langsung disisi lain ia harus memproduksi perak lagi serta anggaran untuk memenuhi kebutuhan sehari-hari keluarganya. Pasar Beringharjo pada masa itu adalah satu-satunya pusat ekonomi rakyat terbesar di Yogyakarta. Pemilik kios tidak hanya berasala dari keluarga pedagang namun dari kalangan bangsawan juga banyak memiliki kios di pasar tersebut yang dioperasikan untuk berdagang. Ratu Kencono Wulan salah atu bangsawan kraton Yogyakarta (1780-1859) diduga banyak memiliki kios di Beringharjo (Carey dan Houben, 2016).

Perusahaan HS Silver Sejak berdiri sudah menjadi anggota KP3Y (Koperasi Produksi Pengusaha Perak Yogyakarta) yang berdomisili di Kotagede. KP3Y adalah koperasi yang mewadahi perusahaan-perusahaan perak yang sebagian besar anggotanya adalah perusahaan perak yang telah berkembang maju. Pada awal tahun 1954 perusahaan HS Silver 800-925 menjadi perusahaan perak dengan nama HS Silver. Nama HS 800-925 berasal dari nama pendiri yakni Bapak. Harto Suharjo yang kemudian dibakukan pada tahun 1990. Sedangkan angka 800-925 adalah kadar kualitas perak atau silver yang digunakan. Pada tahun 1965 membuka Toko atau Art Shop untuk pemasaran produk perak di Jl. Mondorakan 1 Kotagede Yogyakarta (sampai sekarang).

Perusahaan HS Silver sebelum berdiri dahulu Pak Harto Suharjo (HS) dan Ibu pada awalnya adalah menjadi pengrajin perak skala kecil. Ibu selaku istri disamping mengasuh anak-anak juga ikut membantu proses pemasaran produk kerajinan perak yang pada awalnya masih banyak produk yang berupa kerajinan imitasi. Pada awalnya produk-produk HS Silver masih berupa imitasi logam kuningan serta aneka ragam perhiasan. Pada kurun waktu tahun 19531960 di rumah Bapak Harto (pendiri HS Silver) dijadikan sebagai tempat "Ngayoh" atau titik jual barang-barang hasil kerajinan perak warga Kotagede (Wawancara dengan Ibu Listiani pada tanggal 2 April 2019 di Kotagede). Apabila dilihat dari sisi historis, model sistem penjualan seperti "ngayoh" sudah sejak awal abad ke-19 dilakukan pengrajin perak rumahan. Bisnis perak pada waktu itu telah mendapatkan pasar baru yang sangat potensial (Nakamura, 2017).

Pada tahun 1970-80-an Kotagede mengalami masa kejayaan perak. Para pengrajin perak skala rumahan biasanya menyerahkan hasil pekerjaan mereka ke pada pengepul perak untuk selanjutnya dikirim ke pasar atau pemesan (wawancara peneliti dengan Bapak Darwinto pada tanggal 10 Juli 2019). Pada waktu itu para pengrajin perak di Kotagede banyak kebanjiran pesanan perak baik dari lokal maupun internasional. Berangkat dari sinilah perkembangan HS Silver semakin maju dan banyak peminat serta permintaan baik dalam Yogyakarta maupun manca negara.

Sejak tahun 1975 HS Silver mulai mendirikan cabang di Bali dengan 
modal pribadi $75 \%$ dan pinjaman dari bank $25 \%$. Pada saat ini jabatan Direktur Utama di HS Silver dipimpin oleh Ibu Sintami (Cucu Ibu Harto). Sedangkan Direktur Finance dijabat oleh Bapak. Margani Nugraha. Direktur Bisnis dan Development dipimpin Ibu Artin Wuryani. Dalam hal mengelola perusahaan, Ibu dan Bapak Harto Suharjo selaku pendiri lebih dominan menekankan proses pengawasan pekerjaan para karyawan HS Silver di dalam rumah. Selain itu berdasarkan penuturan para karyawan, Ibu Harto termasuk sosok yang bersahaja. Sosok Ibu dalam tradisi Jawa sejak lama menjadi factor penting dalam perkembangan pendidikan anak-anaknya tidak terkecuali dalam hal mengembangkan bisnis keluarga. Pada abad ke-18 sosok perempuan atau Ibu selain pandai dalam berdagang juga turut serta mengikuti jejak suami dalam memimpin pasukan perang melawan kolonial penjajah (Carey dan Houben, 2016).

Beberapa hal yang sangat diperhatikan dalam proses produksi perak di perusahaan HS Silver adalah masalah kebersihan seperti bekas-bekas sampah plastik, box dan sejenisnya yang harus selalu tersusun rapi dan tidak boleh tercecer. Apabila dari segi kerapian, ruangan produksi perak di HS Silver sangat terpola sekaligus tertata dengan rapi dan baik. Ruangan produksi perak tersebut tidak jauh dari ruangan pameran tempat jual-beli kerajinan perak yang sudah jadi bahkan siap diekspor ke mancanegra.

Bapak Harto dan Ibu Harto selaku pendiri perusahaan HS Silver memiliki 8 orang putera terdiri dari 2 puteri dan 6 putera. Anak yang puteri sudah meninggal dua-duanya sedangkan 6 puteranya melanjutkan sekolah akademi kemudian melanjutkan bisnis keluarga. Pada saat ini usia Ibu Harto sudah 87 tahun sedangkan Bapak Suharto sudah meninggal. Sejak berdiri sampai tahun 1990 perusahaan dipimpin dan dikelola langsung oleh Bapak/Ibu H.Harto Suharjo dengan sistem manajemen sederhana. Mulai tahun 1990 manajemen dipimpin oleh putranya dengan penerapan manajemen baru. Seluruh pekerja yang berada di HS Silver khusus produksi silver sebanyak 40an karyawan yang banyak didominasi oleh perempuan di mana sebagian besar dari mereka adalah warga lokal Yogyakarta.

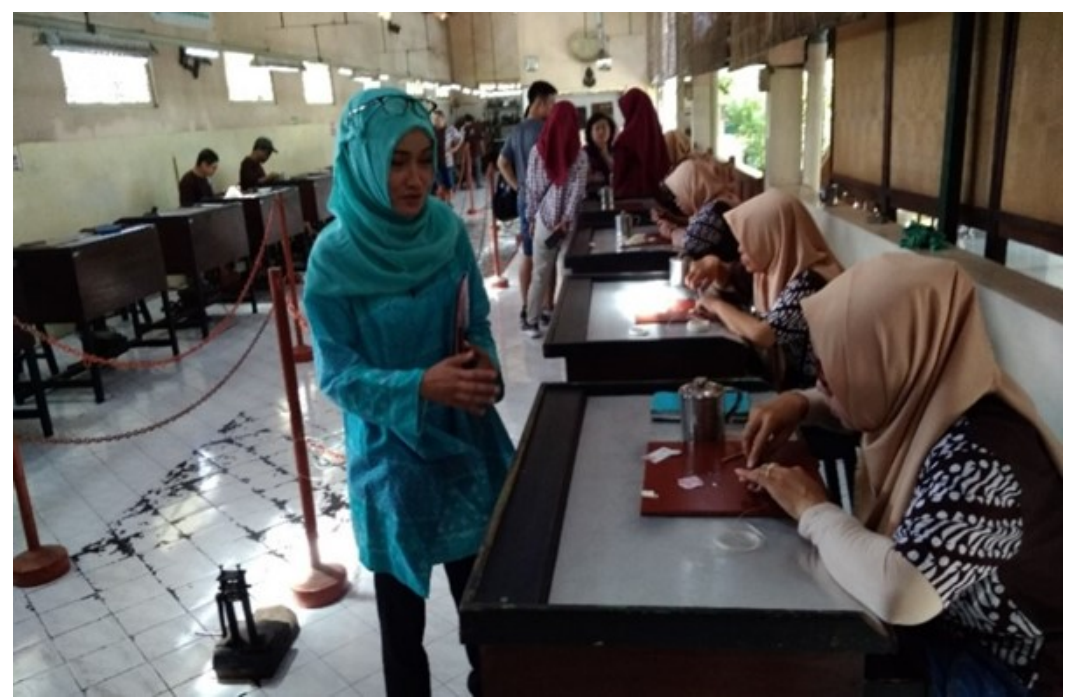

Gambar 1. Ibu Listiani sedang berkomunikasi dengan para pengrajin pembuat motif perhiasan perak HS Silver 
Berdasarkan gambar di atas dapat dijelaskan bahwa para pengrajin perak di HS Silver mayoritas didominasi oleh kaum perempuan. Sebagian besar dari mereka membuat motif atau desai perak berupa cincin, dan aneka motif perhiasan perak lainnya yang sudah menjadi pesanan pembeli. Mereka biasa bekerja mulai dari jam 08.00 WIB sampai pukul 15.00 WIB. Ada dua tipe katagori pengrajin di HS Silver. Pertama adalah pengrajin borongan yaitu pengrajin perak yang mendapat upah sesuai dengan jumlah hasil produksi yang dikerjakan sesuai target yang ditentukan oleh perusahaan. Kedua adalah pengrajin tetap yaitu pengrajin perak di HS Silver yang mendapat gaji tetap tiap bulan sesuai dengan UMR dan mendapat asuransi kesehatan dari perusahaan. Seluruh pengrajin perak HS Silver bekerja di bawah kendali kontrol manajer devisi produksi perak. Sedangkan dalam hal pemasaran dibawah kendali manajer pemasaran.

Secara manajemen, sistem administrasi dan akuntansi mulai dikembangkan di HS Silver dari manual menuju kekomputerisasi sejak awal 1991, hingga sekarang seluruhnya sudah melalui operasi komputer untuk sistem administrasi dan akunting. Sejarah perkembangan manajemen terutama manajemen mutu di HS Silver dapat dilihat dengan mendapat sertifikat ISO 9000 Seri B pada bulan Maret 1998 dengan badan penguji PT. Sucofindo Jakarta, dan Sertifikat ISO 2000 Versi 9001 pada bulan Agustus 2002 dengan badan penguji RW TUV. Pada saat berdiri jumlah karyawan hanya terdiri dari $5 \mathrm{~s} / \mathrm{d} 10$ orang yang semuanya adalah perajin administrasi sedangkan untuk proses pemasaran langsung dipegang oleh Bapak/Ibu H.Harto Suharjo.Kemudian setelah perusahaan HS Silver berkembang dimulailah merekrut karyawan dibidang Administrasi dan pemasaran, dan melibatkan banyak pengrajin dari daerah luar Kotagede bahkan luar Yogyakarta. Sejak 1995 HS Silver 800-925 telah menggunakan Konsultan atau Psikologi dalam menentukan masalah SDM. Selain itu juga dilakukan berbagai pelatihan kepemimpinan terhadap seluruh karyawan.Untuk meningkatkan keterampilan karyawan, perusahaan beberapakali mengikuti Diklat dan pelatihan yang diadakan antara lain oleh Departemen Perindustrian dan Depnaker.

Tabel 1. Data Karyawan HS Silver 2019

\begin{tabular}{|c|c|c|c|c|c|}
\hline $\begin{array}{c}\text { Jenis } \\
\text { Kelamin }\end{array}$ & Pendidikan & $\begin{array}{l}\text { Asal } \\
\text { DIY }\end{array}$ & $\begin{array}{c}\text { Asal Luar } \\
\text { DIY }\end{array}$ & $\begin{array}{l}\text { Kapasitas } \\
\text { Produksi }\end{array}$ & $\begin{array}{c}\text { Hasil } \\
\text { Produksi }\end{array}$ \\
\hline $\begin{array}{l}18 \text { orang } \\
1 \mathrm{k} \text { dan } 22 \\
\text { orang pr }\end{array}$ & $\begin{array}{l}\text { SMA } 85 \% \\
\text { dan } \\
\text { Akademi } \\
15 \%\end{array}$ & $\begin{array}{c}150 \\
\text { orang }\end{array}$ & 5 orang & $\begin{array}{l}100 \\
\mathrm{Kg} / \text { bulan }\end{array}$ & $\begin{array}{l}\text { Perhiasan, } \\
\text { dekorasi } \\
\text { dan aneka } \\
\text { silver }\end{array}$ \\
\hline
\end{tabular}

Berdasarkan data tabeldi atas dapat dijelaskan bahwa jumlah karyawan yang berada di dalam manajemen HS Silver sampai tahun 2015 hingga tahun 2019 adalah 40 orang dengan data statistik jumlah kelamin laki-laki: 18 Orang, perempuan 22 orang dengan rata-rata tamatan Sekolah Menengah berjumlah $85 \%$ dan akademi $15 \%$. Jumlah pengrajin seluruhnya yang bekerjasama dengan HS Silver di daerah wilayah DIY sebanyak 150 orang sedangkan di luar DIY kurang lebih sebanyak 50 orang. Kapasitas produksi perak tiap bulan sebanyak 100 Kg. Hasil Produksi 1). Perhiasan (Bros, Anting, Giwang, Cincin sebanyak 
75\%. 2). Dekorasi (Miniatur, Hiasan Dinding) sebanyak15\% 3). Macammacam silver (piring, sendok, gelassebesar 10\%.Bahan baku pembuatan kerajinan terbuat dari perak aciryang diperoleh dari Logam Mulia (PT Aneka Tambang), Koperasi Produksi Pengusaha Perak Yogyakarta (KP3Y) dan Pasar Bebas (Yogya, Jakarta dan Bali).

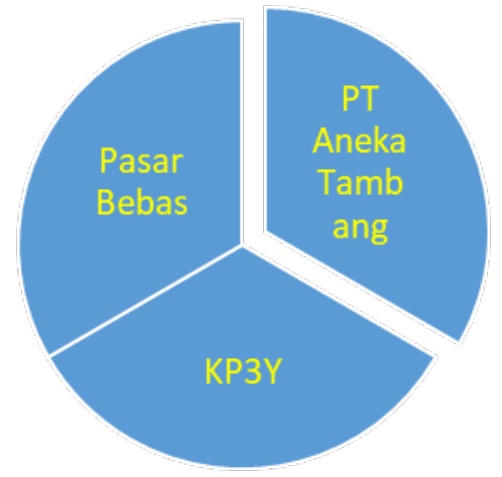

Gambar 2. Diagram sumber bahan baku perak HS. Silver

Pada Gambar 2. dapat dijelaskan bahwasanya sejak tahun 1960-an, hasil kerajinan perak di perusahaan HS Silver sangat bergantung dari jumlah stok bahan baku perak dari pihak eksternal. Pada saat ini dengan kapasitas produksi perak tiap bulan sebanyak $100 \mathrm{~kg}$ maka pihak perusahaan membutuhkan beberapa pasokan bahan baku perak dari beberapa pihak. Bahan baku pembuatan kerajinan yang terbuat dari perak acirdiperoleh hasil pasokan dari Logam Mulia (PT Aneka Tambang) sebesar 30\% atau sekitar $30 \mathrm{~kg}$ perak acir/bulan. Bahan baku perak lainnya didapatkan dari pasokanKoperasi Produksi Pengusaha Perak Yogyakarta (KP3Y) sebanyak 40\% atau sebesar 40 $\mathrm{kg}$ perak/bulan. Sisanya adalah diperolah dari pasokan Pasar Bebas (Yogya, Jakarta dan Bali) sebesar $30 \%$ atau $30 \mathrm{~kg} /$ bulan. Dengan demikian pasokan perak terbesar berasal dari KP3Y sedangkan sisanya didatangkan dari luar Yogyakarta seperti Jakarta dan Bali. Hal ini dapat ditarik kesimpulan bahwa dalam hal pasokan bahan baku pembuatan kerajinan perak praktis HS. Silver tidak memiliki kesulitan karena sudah bekerjasama dengan ebberapa pihak yang selalu siap memasok bahan baku perak pada tiap bulannya.

Secara historis, sejak tahun 1970-an, perusahaan HS Silver mulai meluaskan daerah pemasaran ke Bali di mana pada tahun 1980 resmi membuka cabang di Jl. Batuyung No.2 Banjar Tgehe Gianyar Bali. Pacila dilihat secara pemasaran, sistem pemasaran HS. Silver dilakukan dengan 2 sistem. 1). Retail/Bijian (Art Shop), 2). Wholesale / Grosir. Sedangkan apabila dilihat dari pola penyebarannya proses pemasaran dibagi menjadi dua area. Pertama adalah daerah pemasaran di dalam negeri sebanyak $40 \%$ sedangkan pemasaran luar negeri sebesar $60 \%$. Wilayah negara tujuan export produk-produk HS Silver dapat diperinci sebagai berikut. Persebaran pemasaran di areaEropa sebanyak 60\%, Timur Tengah 30\%, Amerika 5\%, dan Asia 5\%. Sedangkan berbagai strategi pesaran dilakukan melalui beberapa cara seperti melakukan promosi produk pameran diLondon pada tahun 1991, PEE/Expo'96 di Kemayoran Jakarta tahun 1996, Asia Biggest di Hongkong tahun 2003 dan Ina Craft (setiap tahun). 
Secara manajemen pemasaran, perusahaan HS Silver menggunakan beberapa strategi marketing diantara adalah: aktif di media sosial, gathering dengan mengundang beberapa komunitas, hotel, fotografer, fotografer, foto sesi serta berbagai even khususnya di Yogyakarta. Selain itu juga menawarkan experience pada tamu untuk praktik membuat kerajinan perak dengan durasi 90 menit dengan pilihan cincin atau liontin dan hasilnya bisa di bawa langsung pulang dengan kualitas seluruh produk perak HS Silver adalah berkadar 92,5\% perak murni.

Tabel 2. Strategi Pemasaran HS Silver

\begin{tabular}{lll}
\hline $\begin{array}{l}\text { Bentuk-Bentuk } \\
\text { Pemasaran }\end{array}$ & Dalam Negeri & Luar Negeri \\
\hline 1). Retail/Bijian (Art Shop), & Seluruh Wilayah & Eropa 60\%, Timur \\
2). Wholesale / Grosir & Indonesia & $\begin{array}{l}\text { Tengah 30\%, Amerika } \\
\end{array}$ \\
& & $5 \%$, dan Asia 5\% \\
\hline
\end{tabular}

Secara kultural, sebagaimana yang selama ini berkembang dalam tradisi masyarakat Jawa bahwa peranan Ibu dalam keluarga memiliki posisi sentral dalam perjalanan perekembangan pendidikan anak-anaknya. Proses pendidikan tersebut biasanya dilakukan melalui pola asuh, wewaler, wasiat, tembang serta praktek kehidupan sehari-hari (Birsyada, et, al, 2017). Proses pendidikan bisnis dalam keluarga HS Silver sebenarnya dapat dilihat melalui perilaku sehari-hari dari keluarga Bapak Harto Suharjo khususnya dari Ibu. Pada saat ini Direktur Finance HS. Silver dipimpin oleh Bapak. Margani Nugroho yang bertanggungjawab dalam bidang keuangan dan sehari-hari di HS Silver. Direktur Utama sendiri dipegang oleh Ibu Sintami yakni cucu dari Ibu Harto (owner HS. Silver). Menurut penuturan Bapak. Margani tujuan dikembangkannya perusahaan HS. Silver hingga saat ini semakin besar karena nilai-nilai yang diwasiatkan oleh ke dua orang tuanya sebagai pendiri HS. Silver. Pesan-pesan itu adalah untuk melestarikan (nguri-uri tradisi dan budaya di Jawa). Menurutnya kunci kesuksesan dalam bisnis adalah: kehati-hatian, niat yang kuat, membuat desain sesuai pasar. Pendiri HS. Silver pada awal mulanya adalah seorang pedagang keliling di Pasar Bringharjo yang menjual aneka perhiasan imitasi.

Berdasarkan penjelasan di atas dapat dijelaskan bahwasanya pola asuh orang tua menentukan perkembangan psikis dan membentuk karakter anakanak ketika mereka telah usia dewasa. Bentuk dan sarana pola asuh yang mengandung pendidikan karakter pada anak-anak dilakukan dilakukan oleh keluarga pendiri HS. Silver melalui dua cara. Pertama adalah melalui nasehat atau dalam masyarakat Jawa sring disebut wewaler atau pitutur. Hal tersebut biasanya disampaikan oleh orang tua ketika satu keluarga sedang berkumpul bersama lalu kemudian orang tua memberikan nasehat-nasehat kepada anakanaknya. Biasanya nasehat-nasehat tersebut isinya terkait pesan-pesan moral untuk masa depan anak yang harus dipegang menjadi pondasi hidup. Kedua adalah melalui contoh atau praktek langsung dalam kehidupan sehari-hari. Orang tua sebagai pendiri HS. Silver selalu mendampingi dan mengajak anakanak dalam mengelola usahanya dari proses produksi hingga pemasaran. Dengan demikian secara tidak langsung nilai-nilai bisnis telah terbentuk sejak 
kecil akrena pola pendampingan dari kedua orang tua.

Nilai-nilai pendidikan yang telah ditanamkan oleh keluarga Bapak Harto selaku pendiri HS. Silver ternyata tidak hanya diberikan kepada anak-anaknya. Pendidikan nilai juga diterapkan pada seluruh karyawannya di HS. Silver baik dari level direksi sampai pengrajin yang paling bawah. Beberapa pendidikan nilai yang diajarkan adalah karakter kejujuran. Hal tersebut sejak awal dipraktekkan oleh pendiri HS. Silver dalam menjalankan bisnis peraknya. Selain jujur juga diimbangi dengan apa yang dinamakan dengan laku prihatin. Prihatin dalam konsep Jawa sering dimaknai sebagai sebuah sikap kerja keras pantang menyerah, tidak berperilaku boros, sederhana serta memiliki keteguhan batin yang kuat. Dengan kekuatan yang demikian maka seseorang dapat menghadapi berbagai persoalan apapun dengan tenang dan pikiran jernih. Biasanya orang Jawa menunjukkannya melalui serangkaian ritual seperti poso, kungkum, ngubeng deso, lek-lekan, zikiran, slametan, nyadran dengan berkunjung ke makam-makam leluhur dan meminta doa' atau ijazah kepada kyai atau orang pintar.

Secara kultural, apa yang dilakukan oleh pendiri HS. Silver sebagaimana dijelaskan di atas adalah mencerminkan sikap hidup yang telah mapan menurut konsepsi Jawa. Menurut (Susesno, 1988:15)hanya dengan cara demikian seseorang yang mengaku "Njowo" atau Jawa akan selalu bersikap sabar dalam menghadapi situasi serumit apapun, termasuk dalam hal menjalankan bisnis. Selain dalam hal bisnis, dalam hal mengarungi kehidupan keluarga, orang Jawa diharuskan sabar dan menerima segala apa yang terjadi pada dirinya dan senantiasa berdo'a mengharap keselamatan pada diri dan keluarganya. Mengenai sikap dan pendidikan karakter yang diterapkan oleh pendiri HS. Silver sebagaimana dijelaskan di atas juga disampaikan oleh salah seorang karyawan HS. Silver yang termasuk generasi awal yang menjelaskan bahwasanya Bapak. Harto dan Ibu selaku pendiri HS. Silver selalu memberikan nasehat kepada seluruh keluarga dan karyawan yang diiringi dengan praktek dalam kehidupan sehari-hari ketika berada dalam lingkup pekerjaan. Beberapa nasehat itu diantaranya adalah jujur, sabar, teliti dan prihatin.

"Sedoyo sing angsal kedah jujur dados ten pundi-pundi kemawon kedah aman mboten neko-neko. HS meniko panjenenganipun prihatin masa mudanya. Riyen ingkang prihatin wongtuone sak niki ingkang ngunduh anak-anake."

(Wawancara dengan Bapak Sadikir pekerja reparasi perak di HS. Silver).

Kutipan pernayataan dari salah satu karyawan senior yang bekerja di HS. Silver sejak tahun 1970 memberikan penjelasan bahwasanya apapun yang sedang dikerjakan termasuk dalam bekerja di perusahaan orang lain yang pertama harus dipegang teguh adalah sikap kejujuran. Jujur dalam hal ini yang dimaksud adalah menjalankan apa yang menjadi tugas dan kewajibannya sebagai karyawan dan tidak berpikir macam-macam seperti berbuat curang, mencuri, berbohong untuk mendapat keuntungan pribadi orang Jawa sering menyebutnya dengan ojo jahil. Jahil adalah suatu sikap mengambil yang bukan milik sendiri tanpa sepengetahuan pemiliknya. Selain itu yang perlu dipegang 
teguh adalah sikap prihatin dalam menjalani kehidupan. Salah satu sikap prihatin adalah tidak mudah mengeluh, selalu bekerja keras dan memberikan hasil yang terbaik. Dalam hal bekerja makna jujur juga dapat dipahami dengan menjaga serta merawat seluruh aset-aset yang dimiliki oleh sang juragan atau pemilik perusahaan serta mau melayani setiap tamu dengan ramah dan sepenuh hati.Selain laku prihatin dan jujur sebenarnya ada hal lain di luar faktor internal yang sangat mendorong kemajuan perusahaan HS. Silver. Salah satu faktor itu adalah jaringan atau networking. Jaringan di sini yang dimaksud adalah jaringan bisnis baik di dalam maupun luar negeri. HS. Silver mulai berkembang pesat ketika membuka cabang perusahaannya pada tahun 1970-an hingga sampai 1980-an. Pada tahun 1990-an hingga 2000-an mulai membangun jaringan ke mancanegara seperti Amerika, Eropa dan Timur Tengah.

\section{SIMPULAN}

Berdasarkan penjelasan-penjelasan sebagaimana dipaparkan di atas penelitian ini dapat simpulkan sebagai berikut. Pertama, perusahaan perak HS Silver beroperasi sejak tahun 1953 didirikan oleh Bapak dan Ibu H.Harto Suharjo (HS)di mana semula bergerak hanya dalam bidang perhiasan imitasi dengan nama "Terang Bulan". Hasil dari produksi perak tersebut kemudian dititipkan di lapak-lapak pasar Beringharjo Yogyakarta. Di Kotagede, tempat HS Silver dijadikan sebagai pengumpul "Ngayoh" kerajinan perak dari para pengrajin perak se-Kotagede. Kedua, pada tahun 1990 mulai dipimpin oleh putranya dengan penerapan manajemen baru dan mulai mengembangkan jejaring bisnis ke mancanegara. Beberapa jaringan bisnis HS. Silver baik di dalam negeri maupun luar negeri di antaranya membuka cabang di daerah Gianyar Bali, membuka jaringan kerjasama pemasaran di Eropa, Amerika Serikat dan Timur Tengah. Selain itu juga ikut berpartisipasi dalam berbagai even pameran produk kreatif baik tingkat nasional maupun internasional.

Ketiga, Pendiri perusahaan HS. Silver menanamkan nilai-nilai pendidikan bisnis baik kepada keluarga mapun seluruh karyawan melalui wewaler atau nasehat-nasehat yang baik serta memberikan contoh dan pendampingan khususnya ketika di dalam bekerja mengelola bisnis perak. Diantara yang diwariskan tersebut adalah: jujur, sabar, sederhana, bersih, rapi, teliti, niat kuat, inovatif, kerja keras. Keempat, perkembangan HS. Silver semakin maju yang diteruskan oleh putra-putranya dilakukan secara sungguhsungguh dan adaptable dengan perkembangan zaman. Kelima, hasil penelitian ini berimplikasi pada mengembangkan temuan Nakamura (1983) yang menyebutkan bahwa kemajuan ekonomi di Kotagede salah satunya karena infiltrasi etika agama Islam puritan. Pada konteks penelitian ini, terdapat hubungan kausalitas dalam perkembangan kemajuan ekonomi masyarakat di Kotagede khususnya dalam bisnis perak dipengaruhi oleh nilai-nilai etika budaya Jawa (Javaneseethics) yang telah lama mengakar dan terwariskan dari generasi ke generasi pada pengusaha pengrajin perak Kotagede. Selain itu kemajuan ekonomi masyarakat di Kotagede khususnya pada kelompok pengusaha pengrajin perak dipengaruhi olehkuatnya jaringan (business network) kerjasama dan pemasaran ke berbagai negara salah satunya Eropa, 
Timur Tengah dan Amerika.

\section{DAFTAR RUJUKAN}

Birsyada, M. I., Wasino, W., Suyahmo, Hermanu Joebagyo (2016) 'Pemikiran Kewirausahaan Keluarga Mangkunegaran’, Paramita - Historical Studies Journal. doi: 10.15294/paramita.v26i2.6697.

Birsyada, M. I., Wasino, W., Suyahmo, S., Hermanu Joebagyo. (2017) 'Bisnis Keluarga Mangkunegaran', Walisongo: Jurnal Penelitian Sosial Keagamaan, 24(1), pp. 111-136. doi: 10.21580/ws.24.1.975.

Birsyada, M. I., Wasino, W., Suyahmo, Hermanu Joebagyo. (2017) 'The business ethics of royal family: Mangkunegara IV, Sufism and economy in Java', International Journal of Applied Business and Economic Research, 15(7), pp. 33-57.

Birsyada, M. I. and Syahruzah, J. K. (2018) 'Social Change In Yogyakarta: Past And Now A Selo Soemardjan Perspective', Historia: Jurnal Program Studi Pendidikan Sejarah, 6(1), pp. 103-116. doi: 10.24127/hj.v6i1.1150.

Carey, P. B. R. and Houben, V. J. H. (2016) Perempuan-perempuan Perkasa: di Jawa Abad XVIII-XIX. KPG (Kepustakaan Populer Gramedia).

Castles, L. (1982) 'Tingkah Laku Agama, Politik dan Ekonomi Di Jawa: Industri Rokok Kretek Kudus, terjemahan J', Sirait. Jakarta: Sinar Harapan.

Creswell, J. W. (2015) 'Penelitian Kualitatif dan Desain Riset (Memilih Diantara Lima Pendekatan)'. Yogyakarta: Pustaka Pelajar.

Geerts, C. (1977) 'Penjaja dan Raja: Perubahan Sosial dan Modernisasi Ekonomi di Dua Kota Indonesia (S. Supomo: Penterjemah)', Jakarta: Gramedia.

Jalil, A. (2012) Spiritual Entrepreneurship: Study Transformasi Spiritualitas Pengusaha Kudus. IAIN Sunan Ampel.

Kersten, C. (2013) 'Review of Mark Woodward, Java, Indonesia and Islam', Sophia. Springer, 52(1), pp. 209-212.

Koentjaraningrat (1994) Kebudayaan Jawa. Balai Pustaka.

Magnis-Suseno, F. (1988) Etika Jawa: Sebuah Analisa Falsafi Tentang Kebijaksanaan Hidup Jawa. Gramedia.

Moertono, S. (2017) Negara dan Kekuasaan di Jawa Abad XVI-XIX. 
Kepustakaan Populer Gramedia.

Mulkhan, M. (2002) 'Bisnis Kaum Sufi', Studi Tarekat dalam Masyarakat Industri, Yogyakarta: Pustaka Pelajar.

Nakamura, M. (1983) Bulan Sabit Muncul Dari Balik Pohon Beringin: Studi Tentang Pergerakan Muhammadiyah di Kotagede, Yogyakarta. Gadjah Mada University Press.

Nakamura, M. (2017) Bulan Sabit Muncul Dari Balik Pohon Beringin Studi Tentang Pergerakan Muhammadiyah di Kotagede, Yogyakarta. Yogyakarta: Suara Muhammadiyah.

Nasir, N. F. (1999) 'Etos Kerja Wirausahawan Muslim. cet'. I Bandung: Gunung Jati Press.

Pujiono (2010) Perilaku Ekonomi Warga NU Kabupaten Pasuruan Dalam Perspektif Hukum Islam. IAIN Sunan Ampel.

Qodir, Z. (2002) Agama Dan Etos Dagang. Pondok Edukasi.

Rachman, M. (2015) 'Pendekatan Penelitian: Kuantitatif, Kualitatif, Mixed, PTK, R\&D', Yogjakarta: Magnum Pustaka Utama.

Ridwan Muhtadi (2011) Malang, Pola Pemahaman Agama Dan Perilaku Ekonomi Masyarakat Perajin Tempe Di Kelurahan Purwantoro Kecamatan Blimbing. IAIN Sunan Ampel.

Sobary Muhammad (2007) Etika Islam: Dari Kesalehan Individual Menuju Kesalehan Sosial. Yogyakarta: LKiS Pelangi Aksara.

Suharso, P., Wasino., Prajanti, Sucihatiningsih DW., Wahyono, Sugeng B.(2018) 'Middle Class Priyayi: Dillema rn the Crossroad of Cultural Changes (Case Study of Lifestyle Changes Midle Class of Priyayi in Yogyakarta)"', 15(7), pp. 81-123.

Wasino (2014) Modernisasi di Jantung Budaya Jawa: Mangkunegaran, 18961944. Penerbit Buku Kompas. 
